\title{
PENGARUH KEBIJAKAN HARGA, PELAYANAN DAN FASILITAS PENDUKUNG TERHADAP KEPUASAN PELANGGAN PADA PT. SUMATERA BERLIAN MOTOR
}

\author{
Anna Zulpiani', Syarifur Ridho ${ }^{2}$ \\ ${ }^{1}$ Alumni Sarjana Ekonomi STIE Labuhanbatu \\ ${ }^{2}$ Dosen Stie Labuhanbatu
}

\begin{abstract}
ABSTRAK
Tujuan Penelitian Ini Adalah: 1) Untuk Mengetahui Pengaruh Kebijakan Harga Terhadap Kepuasan Pelanggan Pada Pt. Sumatera Berlian Motor, 2) Untuk Mengetahui Pengaruh Pelayanan Terhadap Kepuasan Pelanggan Pada Pt. Sumatera Berlian Motor Dan Untuk Mengetahui Pengaruh Fasilitas Pendukung Terhadap Kepuasan Pelanggan Pada Pt. Sumatera Berlian Motor. Hipotesis Penelitian Adalah Variabel Kebijakan Harga Berpengaruh Signifikan Terhadap Kepuasan Pelanggan Pada Pt. Sumatera Berlian Motor, Variabel Pelayanan Berpengaruh Signifikan Terhadap Kepuasan Pelanggan Pada Pt. Sumatera Berlian Motor Dan Variabel Fasilitas Pendukung Berpengaruh Terhadap Kepuasan Pelanggan Pada Pt. Sumatera Berlian Motor. Populasi Dari Penelitian Ini Adalah Pelanggan Yang Melakukan Pembelian Pada PT. Sumatera Berlian Motor. Jumlah Populasinya Adalah Sebanyak 98 Responden. Hasil Penelitian Menunjukkan Bahwa: 1) Kebijakan Harga Berpengaruh Positif Dan Signifikan Terhadap Kepuasan Pelanggan Pada Pt. Sumatera Berlian Motor, Pelayanan Berpengaruh Positif Dan Signifikan Terhadap Kepuasan Pelanggan Pada Pt. Sumatera Berlian Motor Dan Fasilitas Pendukung Berpengaruh Positif Dan Signifikan Terhadap Kepuasan Pelanggan Pada Pt. Sumatera Berlian Motor.
\end{abstract}

Kata Kunci: Kebijakan Harga, Pelayanan, Fasilitas Pendukung, Kepuasan Pelanggan.

\section{Pendahuluan}

Pada era bisnis saat ini, persaingan dalam dunia bisnis semakin bertambah ketat. Persaingan yang semakin ketat ini menuntut para pelaku bisnis untuk mampu memaksimalkan kinerja perusahaannya agar dapat bersaing di pasar. Perusahaan harus berusaha keras untuk mempelajari dan memahami kebutuhan dan keinginan pelanggannya. Dengan memahami kebutuhan, keinginan dan permintaan pelanggan, maka akan memberikan masukan penting bagi perusahaan untuk merancang strategi pemasaran agar dapat menciptakan kepuasan bagi pelanggannya (Kotler dan Amstrong, 2007).

Perusahaan harus menempatkan orientasi pada kepuasan pelanggan sebagai tujuan utama. Hal ini tercermin dari semakin banyaknya perusahaan yang menyertakan komitmennya terhadap kepuasan pelanggan dalam pernyataan misinya, iklan, maupun public relation release. Kunci utama perusahaan untuk memenangkan persaingan adalah memberikan nilai dan kepuasan kepada pelanggan melalui penyampaian produk dan jasa yang berkualitas dengan harga yang bersaing. 
Berdasarkan data dari Sumatera Berlian Motor kebijakan harga, pelayanan dan fasilitas yang ditawarkan pun berbeda antara satu dengan yang lainnya, sehingga dengan begitu akan menjadi ciri dan keunggulan tersendiri bagi perusahaan. Dengan semakin meningkatnya persaingan yang ada, perusahaan harus mengetahui faktor-faktor yang mempengaruhi kepuasan pelanggannya agar dapat melakukan perbaikan dan inovasi yang diharapkan dapat meningkatkan kepuasan pelanggan.

Sebuah kebijakan harga adalah Motto atau tindakan yang dirancang untuk mempengaruhi dan menentukan keputusan harga. Kebijakan harga menentukan pertimbangan biaya pengembangan dan periode waktu di mana mereka bertujuan untuk menutup biaya ini, dan bagaimana dengan mudah dan cepat pesaing dapat memasuki pasar. promosi penjualan yang memadai dapat menjamin peningkatan penjualan dalam waktu singkat.

Berdasarkan pengamatan pada PT. Sumatera Berlian Motor pelayanan yang diberikan kepada pelanggan masih kurang, terlihat dari kesibukan para karyawan dalam menangani suatu kendaraan tanpa adanya komunikasi yang kurang baik. Kurangnya keramahan diantara karyawan dengan pelanggan sehingga pelanggan merasa tidak puas.

Selain kebijakan harga, faktor fasilitas juga merupakan faktor yang penting dalam menentukan kepuasan konsumen. Faktor fasilitas untuk memilih suatu produk khususnya produk jasa, dimana fasilitas yang lengkap dan memadai yang diberikan akan membuat konsumen merasa puas terhadap produk yang dipakainya.

Konsumen akan mengalami salah satu tingkat kepuasan konsumen secara umum dimana, apabila pelayanan yang diberikan tidak sesuai dengan harapan konsumen maka konsumen akan merasa kecewa, sedangkan apabila pelayanan yang diberikan sesuai dengan harapan konsumen, maka konsumen merasa puas. Untuk memenuhi kepuasan konsumen pada perusahaan, maka kualitas pelayanan yang memadai dan kebijakan harga produk merupakan hal yang harus dikelola baik oleh pihak perusahaan. Tjiptono (2007) Kualitas pelayanan merupakan tingkat keunggulan yang diharapkan dan pengendalian atas tingkat keunggulan untuk memenuhi keinginan konsumen.

Berdasarkan pada latar belakang masalah di atas, maka tujuan yang ingin dicapai dalam penelitian ini adalah untuk menganalisis "Pengaruh Kebijakan harga, Pelayanan, dan Fasilitas pendukung terhadap Kepuasan Pelanggan pada PT. Sumatera Berlian Motor.

\section{Perumusan Masalah}

Berdasarkan latar belakang diatas maka perumusan masalah dalam penelitian ini adalah :

1. Apakah kebijakan harga berpengaruh terhadap Kepuasan Pelanggan pada PT. Sumatera Berlian Motor?

2. Apakah pelayanan berpengaruh terhadap Kepuasan Pelanggan pada PT. Sumatera Berlian Motor?

3. Apakah fasilitas pendukung berpengaruh terhadap Kepuasan Pelanggan pada PT. Sumatera Berlian Motor?

4. Apakah Kebijakan harga, Pelayanan, dan Fasilitas pendukung berpengaruh terhadap Kepuasan Pelanggan pada PT. Sumatera Berlian Motor? 


\section{Tujuan Penelitian}

Secara umum tujuan penelitian ini adalah untuk mengetahui Pengaruh Kebijakan harga, Pelayanan, dan Fasilitas pendukung terhadap Kepuasan Pelanggan pada PT. Sumatera Berlian Motor. Adapun tujuan penelitian ini adalah sebagai berikut:

1. Mengetahui pengaruh kebijakan harga terhadap Kepuasan Pelanggan pada PT. Sumatera Berlian Motor.

2. Mengetahui pengaruh pelayanan terhadap Kepuasan Pelanggan pada PT. Sumatera Berlian Motor

3. Mengetahui pengaruh fasilitas pendukung terhadap Kepuasan Pelanggan pada PT. Sumatera Berlian Motor

4. Mengetahui pengaruh Kebijakan harga, Pelayanan, dan Fasilitas pendukung terhadap Kepuasan Pelanggan pada PT. Sumatera Berlian Motor

\section{Manfaat Penelitian}

1. Bagi perusahaan

Sebagai masukan bagi PT. Sumatera Berlian Motor dalam upayanya merumuskan strategi pemasaran yang tepat guna meningkatkan dan mengembangkan kepuasan pelanggan

2. Bagi Peneliti

Sebagai wadah untuk menambah wawasan dan memperluas pengetahuan dalam masalah pemasaran dalam meningkatkan kepuasan pelanggan yang ada pada perusahaan sehingga dapat dipergunakan sebagai bahan referensi ilmu pengetahuan.

3. Bagi Penelitian selanjutnya

Hasil penelitian ini diharapkan dapat menjadi informasi tambahan bagi peneliti selanjutnya dan bagi

$\begin{array}{lcr}\text { perusahaan } & \text { yang } & \text { menghadapi } \\ \text { masalah } & \text { mengenai } & \text { kepuasan } \\ \text { pelanggan. } & & \end{array}$

\section{Landasan Teori}

Kebijakan Harga

Harga merupakan salah satu atribut penting yang dievaluasi oleh konsumen sehingga manajer perusahaan perlu benar-benar memahami peran tersebut dalam mempengaruhi sikap konsumen. Harga sebagai atribut dapat diartikan bahwa harga merupakan konsep keanekaragaman yang memiliki arti berbeda bagi tiap konsumen, tergantung karakteristik konsumen, situasi dan produk.

\section{Pengertian Pelayanan}

Salah satu cara agar penjualan jasa satu perusahaan lebih unggul dibandingkan para pesaingnya adalah dengan memberikan pelayanan yang berkualitas dan bermutu yang memenuhi tingkat kepentingan konsumen. Tingkat kepentingan konsumen terhadap jasa yang akan mereka terima dapat dibentuk berdasarkan pengalaman dan saran yang mereka peroleh. Konsumen memilih pemberi jasa berdasarkan peringkat kepentingan. Dan setelah menikmati jasa tersebut mereka cenderung akan membandingkannya dengan yang mereka harapkan.

Pelayanan adalah kunci keberhasilan dalam berbagai usaha pada kegiatan yang sifatnya jasa. Peranannya akan lebih besar dan menentukan jika pada kegiatan jasa tesebut kompetisi (persaingan) cukup ketat dalam upaya merebut pangsa pasar atau langganan. Tingkat pelayanan merupakan suatu tingkat yang ditunjukkan oleh pusat pelayanan dalam menangani orang-orang yang memerlukan pelayanan-pelayanan. 
Menurut Barata (2005 : 10) bahwa :" Suatu pelayanan akan terbentuk karena adanya proses pemberian layanan tertentu dari pihak penyedia layanan kepada pihak yang dilayani."

\section{Fasilitas Pendukung}

Pemasaran Online dilakukan
memalui system komputer online interaktif, yang menghubungkan pembeli dan penjual secara elektronik. Ada 2 (dua ) jenis saluran pemasaran online : Layanan Online Komersial, Internet layanan yang menawarkan informasi dan layanan pemasaran online kepada pelanggan yang membayar biaya bulanan, seperti America online, Compuserve dan Prodigy. Internet, Web global jaringan komputer yang luas dan berkembang pesat yang tidak mempunyai manajemen dan kepemilikan sentral. Perkembangan pemasaran online Perdagangan elektronik ( E-Commerce ) adalah istilah umum untuk proses pembelian dan penjualan yang didukung oleh sarana elektronik.

Menurut Tjiptono (2007:184) fasilitas adalah sumber daya fisik yang harus ada sebelum suatu jasa dapat ditawarkan kepada konsumen. Fasilitas dapat pula berupa segala sesuatu yang memudahkan konsumen dalam memperoleh kepuasan. Karena suatu bentuk jasa tidak bisa dilihat, tidak bisa dicium dan tidak bisa diraba maka aspek wujud fisik menjadi penting sebagai ukuran dari pelayanan. Pelanggan akan menggunakan indera penglihatan untuk menilai suatu kualitas pelayanan.

\section{Pengertian Pelanggan}

Kata pelanggan adalah istilah yang sangat akrab dengan dunia bisnis di Indonesia, dimulai dari pedagang kecil hingga pedagang besar, dari industri rumah tangga hingga industri berskala internasional, dari perusahaan yang bergerak di bidang produksi barang hingga perusahaan yang bergerak di bidang jasa sangat mengerti apa arti kata pelanggan itu. Tetapi apakah mereka memiliki persepsi yang sama terhadap pelanggan, apakah mereka sama-sama mengetahui apa yang diinginkan pelanggan, apakah mereka sama-sama menganggap pelanggan adalah orang yang membeli produk dan menggunakan jasa. Perbedaan persepsi mereka terhadap pelanggan akan mengakibatkan perbedaan dalam memberikan pelayanan.

Yamit (2006 : 75) mengemukakan bahwa secara tradisional pelanggan diartikan "orang yang membeli produk." Dalam perusahaan yang bergerak dibidang jasa, pelanggan adalah orang yang menggunakan jasa pelayanan. Dalam dunia pemasaran pelanggan diartikan sebagai konsumen, pandangan tradisional ini menyimpulkan, bahwa pelanggan adalah orang yang berinteraksi dengan perusahaan setelah proses produksi selesai, karena mereka adalah

\section{Pengertian Kepuasan Pelanggan}

Menurut Lupiyoadi (2008:158) "kepuasan merupakan tingkat perasaan di mana seseorang menyatakan hasil perbandingan atas kinerja produk/jasa yang diterima dan yang diharapkan". Kepuasan dan ketidakpuasan pelanggan akan suatu produk sebagai akhir dari suatu proses penjualan memberikan dampak tersendiri kepada perilaku pelanggan terhadap produk tersebut. Kepuasan konsumen dapat tercapai dengan adanya kegiatan pemasaran, karena tujuan pemasaran adalah memenuhi dan memuaskan kebutuhan konsumen.Kepuasan konsumen dapat ditunjukkan melalui sikap pembelian. 


\section{Hasil Penelitian Dan Pembahasan Uji Normalitas}

Uji normalitas merupakan persyaratan penting yang harus terpenuhi dalam analisis regresi. Uji ini digunakan untuk mengetahui apakah dalam sebuah model regresi, variabel dependen memiliki distribusi normal atau tidak.

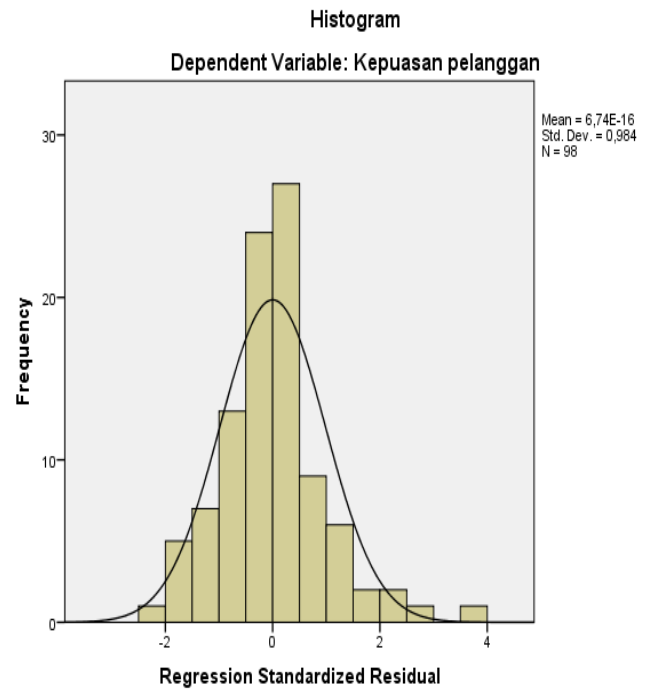

\section{Gambar 1 Uji Normalitas}

Dari gambar diatas dapat dilihat bahwa data menyebar disekitar diagram dan mengikuti model regresi sehingga dapat disimpulkan bahwa data yang diolah merupakan data yang berdistribusi normal, maka model regresi memenuhi asumsi normal.

\section{Uji Multikolinearitas}

Uji multikolinearitas digunakan untuk menguji adanya hubungan linear yang sempurna (mendekati sempurna) antara beberapa atau semua variabel bebas.
Tabel 1

Uji Multikolinearitas Coefficients $^{\mathbf{a}}$

\begin{tabular}{|c|c|c|}
\hline \multirow[b]{2}{*}{ Model } & \multicolumn{2}{|c|}{$\begin{array}{c}\text { Collinearity } \\
\text { Statistics }\end{array}$} \\
\hline & Tolerance & VIF \\
\hline 1 (Constant) & & \\
\hline Kebijakan harga & ,839 & 1,192 \\
\hline Pelayanan & ,888 & 1,127 \\
\hline Fasilitas pendukung &, 835 & 1,197 \\
\hline
\end{tabular}

a. Dependent Variable: Kepuasan pelanggan

Dari tabel uji multikolinearitas diketahui bahwa nilai tolerance kebijakan harga yaitu 0,839 $>0,1$ maka tidak terjadi multikolinearitas , pelayanan yaitu 0,888 $>0,1$ maka tidak terjadi multikolinearitas, dan fasilitas pendukung yaitu $0,835>0,1$ maka tidak terjadi multikolinearitas.

Berdasarkan uji multikolinearitas diketahui bahwa nilai VIF dari kebijakan harga yaitu $1,192<10$ maka tidak terjadi multikolinearitas, nilai VIF pelayanan yaitu $1,127<10$ maka tidak terjadi multikolinearitas dan VIF fasilitas pendukung yaitu $1,197<10$ maka tidak terjadi multikolinearitas.

\section{Uji Heteroskedastisitas}

Uji heteroskedastisitas digunakan untuk mendeteksi apakah dalam model regresi terjadi ketidaksamaan varian dari residual satu pengamatan ke pengamatan lain.

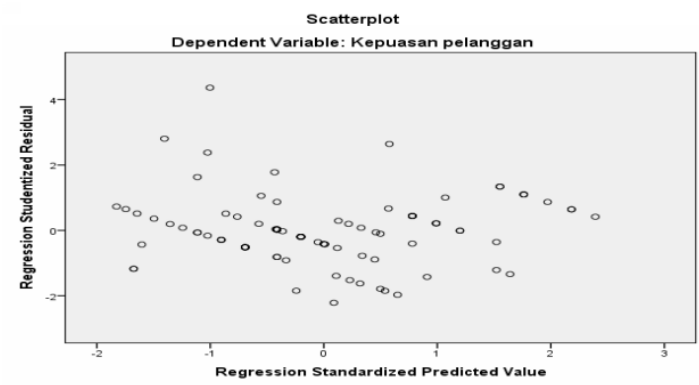

Gambar 2 Uji Heteroskedastisitas 
Dari gambar diatas dapat diketahui bahwa titik yang ada tidak membentuk suatu pola tertentu seperti titik-titik menyebar diatas dan dibawah angka 0 pada sumbu Y, maka tidak terjadi heteroskedastisitas.

\section{Hasil Analisis Regresi Berganda}

Analisis ini digunakan untuk mengetahui pengaruh variabel bebas (kebijakan harga, pelayanan dan fasilitas pendukung) terhadap variabel terikat (kepuasan pelanggan). Hasil analisis regresi sebagai berikut:

Tabel 2

Hasil Analisis Regresi Linear Berganda

Coefficients $^{\mathrm{a}}$

\begin{tabular}{|c|c|c|c|c|c|}
\hline \multirow[b]{2}{*}{ Model } & \multicolumn{2}{|c|}{$\begin{array}{l}\text { Unstandardize } \\
\text { d Coefficients }\end{array}$} & \multirow{2}{*}{$\begin{array}{c}\begin{array}{c}\text { Standardized } \\
\text { Coefficients }\end{array} \\
\text { Beta }\end{array}$} & \multirow[b]{2}{*}{$\mathrm{t}$} & \multirow[b]{2}{*}{ Sig. } \\
\hline & B & $\begin{array}{l}\text { Std. } \\
\text { Error }\end{array}$ & & & \\
\hline 1 (Constant) & 2,835 & 1,972 & & 1,438 & ,154 \\
\hline Kebijakan harga & ,203 & ,057 & 275 & 3,583 & ,001 \\
\hline Pelayanan & ,266 & 091 & 218 & 2,925 & ,004 \\
\hline Fasilitas pendukung & ,419 &, 067 & ,478 & 6,221 &, 000 \\
\hline
\end{tabular}

a. Dependent Variable: Kepuasan pelanggan

Hasil pengolahan komputer dapat diketahui persamaan koefisien regresi linier berganda yang diperoleh sebagai berikut:

$\mathrm{Y}=2,835+0,203 \mathrm{X}_{1}+0,266 \mathrm{X}_{2}+0,419$ $\mathrm{X}_{3}$

\section{Koefisien Determinasi $\left(\mathbf{R}^{\mathbf{2}}\right)$}

Analisis ini digunakan untuk mengetahui seberapa besar sumbangan atau pengaruh yang diberikan variabel bebas terhadap variabel terikat yang ditunjukkan dengan persentase. Hasil koefisien determinasi sebagai berikut:
Tabel 4 Hasil Uji t 


\section{Coefficients ${ }^{\mathrm{a}}$}

\begin{tabular}{|c|c|c|c|c|c|}
\hline \multirow{2}{*}{ Model } & \multicolumn{2}{|c|}{$\begin{array}{c}\text { Unstandardized } \\
\text { Coefficients }\end{array}$} & \multirow{2}{*}{$\begin{array}{c}\begin{array}{c}\text { Standardized } \\
\text { Coefficients }\end{array} \\
\text { Beta }\end{array}$} & \multirow{2}{*}{$\mathrm{t}$} & \multirow{2}{*}{ Sig. } \\
\hline & B & $\begin{array}{l}\text { Std. } \\
\text { Error }\end{array}$ & & & \\
\hline \multirow{4}{*}{$\begin{array}{ll}1 & \text { (Constant) } \\
\text { Kebijakan harga } \\
\text { Pelayanan } \\
\text { Fasilitas } \\
\text { pendukung }\end{array}$} & 2,835 & 1,972 & & 1,438 &, 154 \\
\hline & ,203 & ,057 & ,275 & 3,583 & ,001 \\
\hline & ,266 & ,091 & ,218 & 2,925 & ,004 \\
\hline & ,419 &, 067 & ,478 & 6,221 & ,000 \\
\hline
\end{tabular}

a. Dependent Variable: Kepuasan pelanggan

Sumber: Data diolah, 2016

1. Hasil perhitungan diperoleh nilai $t$ hitung $(3,583)>$ dari $t$ tabel $(1,665)$ maka Ho ditolak dan Ha diterima, sehingga variabel kebijakan harga berpengaruh secara signifikan terhadap kepuasan Pelanggan pada PT. Sumatera Berlian Motor.

2. Hasil perhitungan diperoleh nilai $t$ hitung $(2,925)>$ dari $\mathrm{t}$ tabel $(1,665)$ maka Ho ditolak dan Ha diterima, sehingga variabel pelayanan berpengaruh secara signifikan terhadap kepuasan Pelanggan pada PT. Sumatera Berlian Motor.

3. Hasil perhitungan diperoleh nilai $t$ hitung $(6,221)>$ dari $\mathrm{t}$ tabel $(1,665)$ maka Ho ditolak dan Ha diterima, sehingga variabel fasilitas pendukung berpengaruh secara signifikan terhadap kepuasan Pelanggan pada PT. Sumatera Berlian Motor.

\section{Uji Hipotesis Secara Simultan (Uji F)}

Uji F digunakan untuk mengetahui signifikans pengaruh variabel bebas secara bersama-sama terhadap variabel terikat. Hasil uji F sebagai berikut:

\begin{tabular}{|l|r|r|r|r|r|}
\hline Model & $\begin{array}{c}\text { Sum of } \\
\text { Squares }\end{array}$ & Df & $\begin{array}{c}\text { Mean } \\
\text { Square }\end{array}$ & \multicolumn{1}{c|}{ F } & Sig. \\
\hline 1 Regression & 155,874 & 3 & 51,958 & 36,281 &, $000^{\mathrm{b}}$ \\
Residual & 134,616 & 94 & 1,432 & & \\
Total & 290,490 & 97 & & & \\
\hline
\end{tabular}

a. Dependent Variable: Kepuasan pelanggan

b. Predictors: (Constant), Fasilitas pendukung, Pelayanan, Kebijakan harga

Sumber: Data diolah,2016

Nilai $F$ hitung $(36,281)>$ dari nilai $\mathrm{F}$ tabel $(2,47)$ dengan nilai signifikan $0,000<0,05$ maka Ho ditolak sehingga ada pengaruh yang signifikan kebijakan harga, pelayanan dan fasilitas pendukung secara simultan terhadap kepuasan Pelanggan pada PT. Sumatera Berlian Motor.

\section{Pembahasan}

\section{Pengaruh kebijakan harga terhadap kepuasan Pelanggan pada PT. Sumatera Berlian Motor \\ Secara analisis deskriptif tentang} kebijakan harga pada kepuasan Pelanggan pada PT. Sumatera Berlian Motor menunjukkan bahwa distribusi jawaban responden paling tinggi skornya adalah pada pernyataan Penetapan harga diskon yang ditawarkan sesuai dengan peraturan perusahaan dengan rata-rata skor 4,7 . Responden yang menjawab setuju $28,6 \%$, responden yang menjawab sangat setuju sebanyak 68,4\%, dan responden yang menjawab kurang setuju sebanyak 3,1\%.

Sedangkan tanggapan responden yang memiliki rata-rata skor paling rendah adalah pada pernyataan Penetapan harga promosi dilakukan pada hari-hari tertentu dengan rata-rata skor 4,2, responden yang menjawab setuju $64,3 \%$, responden yang menjawab sangat setuju sebanyak 27,6\%, dan responden yang menjawab kurang setuju sebanyak $8,2 \%$.

Hasil pengujian koefisien kebijakan harga terhadap kepuasan

\section{Tabel 5 \\ Hasil Uji F}

ANOVA ${ }^{\mathrm{a}}$ 
pelanggan pada PT. Sumatera Berlian Motor memiliki jalur positif sebesar 0,203 yang berarti semakin baik kebijakan harga akan meningkatkan kepuasan pelanggan. Nilai probabilitas (p) sebesar 0,001 yang berarti ada pengaruh signifikan kebijakan harga terhadap kepuasan pelanggan.

\section{Pengaruh pelayanan terhadap kepuasan Pelanggan pada PT. Sumatera Berlian Motor}

Secara analisis deskriptif tentang pelayanan pada kepuasan Pelanggan pada PT. Sumatera Berlian Motor menunjukkan bahwa distribusi jawaban responden paling tinggi skornya adalah pada pernyataan Karyawan selalu mencatat jenis barang setiap unit sebagai bukti fisik dengan rata-rata skor 4,2. Responden yang menjawab sangat setuju $24,5 \%$, responden yang menjawab setuju sebanyak $69,4 \%$, dan responden yang menjawab kurang setuju sebanyak $6,1 \%$.

Sedangkan tanggapan responden yang memiliki rata-rata skor paling rendah adalah pada pernyataan Karyawan dapat merasakan empati terhadap pelanggan dengan rata-rata skor 3,6, responden yang menjawab setuju $66,3 \%$, responden yang menjawab sangat setuju sebanyak $11,2 \%$, dan responden yang menjawab kurang setuju sebanyak $11,2 \%$.

Hasil pengujian koefisien pelayanan terhadap kepuasan pelanggan pada PT. Sumatera Berlian Motor memiliki jalur positif sebesar 0,266 yang berarti semakin baik pelayanan akan meningkatkan kepuasan pelanggan. Nilai probabilitas (p) sebesar 0,004 yang berarti ada pengaruh signifikan pelayanan terhadap kepuasan pelanggan.

\section{Pengaruh fasilitas pendukung terhadap kepuasan Pelanggan pada PT. Sumatera Berlian Motor}

Secara analisis deskriptif tentang fasilitas pendukung pada kepuasan Pelanggan pada PT. Sumatera Berlian Motor menunjukkan bahwa distribusi jawaban responden paling tinggi skornya adalah pada pernyataan Ruang tunggu tertata dengan rapi dengan rata-rata skor 4,5 . Responden yang menjawab sangat setuju $51 \%$, responden yang menjawab setuju sebanyak $43,9 \%$, dan responden yang menjawab kurang setuju sebanyak $5,1 \%$.

Sedangkan tanggapan responden yang memiliki rata-rata skor paling rendah adalah pada pernyataan Perusahaan menyediakan toilet yang bersih dengan rata-rata skor 4,1. Responden yang menjawab setuju $67,3 \%$, responden yang menjawab sangat setuju sebanyak $22,4 \%$, dan responden yang menjawab kurang setuju sebanyak $10,2 \%$.

Hasil pengujian koefisien fasilitas pendukung terhadap kepuasan pelanggan pada PT. Sumatera Berlian Motor memiliki jalur positif sebesar 0,419 yang berarti semakin baik fasilitas pendukung akan meningkatkan kepuasan pelanggan. Nilai probabilitas (p) sebesar 0,000 yang berarti ada pengaruh signifikan fasilitas pendukung terhadap kepuasan pelanggan.

\section{Kesimpulan}

Hasil penelitian dan pembahasan tentang pengaruh kebijakan harga, pelayanan dan fasilitas pendukung terhadap kepuasan Pelanggan pada PT. Sumatera Berlian Motor, maka penulis mengambil kesimpulan :

1. Secara parsial kebijakan harga memiliki pengaruh positif terhadap kepuasan Pelanggan pada PT. 
Sumatera Berlian Motor sebesar 0,203 yang berarti semakin baik kebijakan harga akan semakin baik kepuasan pelanggan.

2. Secara parsial pelayanan memiliki pengaruh positif terhadap kepuasan Pelanggan pada PT. Sumatera Berlian Motor sebesar 0,266 yang berarti semakin baik pelayanan akan meningkatkan kepuasan pelanggan.

3. Secara parsial fasilitas pendukung memiliki pengaruh positif terhadap kepuasan Pelanggan pada PT. Sumatera Berlian Motor sebesar 0,419 yang berarti semakin baik fasilitas pendukung akan meningkatkan kepuasan pelanggan.

4. Secara simultan kebijakan harga, pelayanan dan fasilitas pendukung berpengaruh positif dan signifikan terhadap kepuasan Pelanggan pada PT. Sumatera Berlian Motor.

\section{Saran}

Berdasarkan temuan hasil penelitian yang telah dikemukakan sebelumnya, maka untuk meningkatkan kepuasan pelanggan adalah sebagai berikut:

1. Hasil penelitian yang menunjukkan bahwa harga, psikologi konsumen dan lokasi secara simultan mempengaruhi keputusan pembelian hendaknya dapat dijadikan masukan dan bahan pertimbangan bagi perusahaan dalam merancang dan menentukan kebijakan pemasaran yang efektif dan efisien terutama dalam mempengaruhi pelanggan, dengan mengetahui apa yang dibutuhkan dan diinginkan oleh pelanggan sehingga akan mengarahkan perusahaan pada penetapan kebijakan pemasaran yang efektif dan efisien terutama dalam rangka mempengaruhi pelanggan. Maka pihak manajemen hendaknya memperhatikan peningkatan bagi kebijakan harga, pelayanan dan fasilitas pendukung yag dimiliki agar mampu mendorong kepuasan pelanggan yang pada akhirnya akan dapat membantu meningkatkan jumlah pelanggan.

2. Selain pelayanan dan fasilitas pendukung, manajemen hendaknya juga memperhatikan indikator dari variabel kebijakan harga yang meliputi kesesuaian harga produk dengan kualitas produk, perbandingan harga dengan harga produk lain atau sejenis dari saingan dan kesesuaian harga produk dengan manfaat yang diperoleh sehingga kebijakan harga terhadap kepuasan pelanggan yang ditetapkan dengan baik.

3. Untuk meningkatkan kepuasan pelanggan, perlu ada penambahan nilai yang ditawarkan. Menambah nilai akan membuat pelanggan merasa bahwa mereka mendapat lebih apa yang mereka bayar atau bahkan lebih dari yang mereka harapkan. Menambah nilai tidak harus berarti menurunkan harga atau memberikan pelayanan tambahan, tetapi dapat dilakukan secara sederhana seperti meningkatkan kenyamanan dan kecepatan pelayanan atau dengan cara mentraining petugas sehingga dapat menjawab kebutuhan pelanggan selain memperhatikan segala fasilitas yang dibutuhkan pelanggan selama menggunakan jasa yang ditawarkan dan akhirnya dapat memuaskan pelanggan. 


\section{DAFTAR PUSTAKA}

Arikunto, Suharsimi. 2012. Prosedur Penelitian. Bina Aksara. Jakarta

Barata, Atep Adya, 2005, Dasar-dasar Pelayanan Prima, cetakan kedua, Penerbit : PT. Elex Media Komputindo, Jakarta

Chandra, Gregorius, 2006. Strategi dan Program Pemasaran. Penerbit : Andi, Yogyakarta

Ghozali, Imam. 2005. Aplikasi Analisis Multivariate dengan Program SPSS. Semarang: Badan Penerbit Universitas Diponegoro

Gitosudarmo, Indriyo, 2008, Manajemen Pemasaran, edisi kedua, cetakan keenam, Penerbit : BPFE Yogyakarta

Kasmir, 2005, Etika Custumer Service, edisi pertama, cetakan pertama, Penerbit : RajaGrafindo Persada, Jakarta

Kotler, Phillip \& Gary Armstrong, 2007. Dasar-dasar Pemasaran. Jakarta: PT. Indeks. Kelompok Gramedia

Lupiyoadi, Rambat. 2006. Manajemen Pemasaran Jasa: Teori dan Praktik. Jakarta: Salemba Empat

Nazir, Moch. 2003. Metode Penelitian. Jakarta: Ghalia Indonesia

Tjiptono, Fandy dan Gregorius Chandra, 2005, Service, Quality dan Satisfaction, Penerbit : Andi, Yogyakarta

Tjiptono, Fandy . 2007, Pemasaran Jasa, Malang: Bayumedia

Widiyanto, Ibnu, 2008, Pointers: Metodologi Penelitian, Semarang: Badan Penerbit Universitas Diponegoro

Yamit, Zulian, 2006, Manajemen Kualitas Produk dan Jasa, penerbit : Ekonisia, Yogyakarta 